Florida State University College of Law

Scholarship Repository

Scholarly Publications

3-2002

Proxy Consent to Organ Donation by Incompetents

Michael T. Morley

Follow this and additional works at: https://ir.law.fsu.edu/articles

Part of the Health Law and Policy Commons 


\title{
Note
}

\section{Proxy Consent to Organ Donation by Incompetents}

\author{
Michael T. Morley
}

\section{INTRODUCTION}

A seven-year-old girl lies in a hospital bed, surrounded by intimidating machines, receiving her twice-weekly dialysis treatment. ${ }^{1}$ Diagnosed with hemolytic-uremic syndrome and malignant hypertension, she has already had both of her kidneys removed. ${ }^{2}$ Her name is Kathleen Hart, and without a kidney transplant from her twin sister, she will likely die. ${ }^{3}$

Since the first kidney transplant involving a living human donor occurred in $1954,{ }^{4}$ noncadaveric organ donations have been an important source of life-saving organs for patients in desperate need, leading to over 40,000 transplants. ${ }^{5}$ A major impediment to such transplants, however, is the lack of available organs from both living and deceased donors. ${ }^{6}$ Further

1. "Dialysis is an artificial means of removing the waste products and extra fluid from the blood when the kidneys are unable to do so on their own. ... For young and otherwise healthy people, transplantation is usually preferred over dialysis because it affords a better quality of life." David E. LARSON, Mayo Clinic Famil y Health BoOK 856 (2d ed. 1996).

2. JOSEPH C. SEGEN, CURRENT MED TALK 372 (1995) (defining hemolytic-uremic syndrome as a "clinical complex often accompanied by a prodrome of bloody diarrhea, most commonly occurring in the summer"),

3. Hart v. Brown, 289 A.2d 386, 387 (Conn. Super. Ct. 1972).

4. John P. Merrill et al., Successful Homotransplantation of the Human Kidney Between Identical Twins, 160 JAMA 277 (1956).

5. From 1988 to $2000,42,920$ of the 233,918 reported organ transplants in the United States involved organs from living donors. United Network for Organ Sharing, Transplants, at http://www.unos.org/Newsroom/critdata_transplants_ustx.htm (last visited Jan. 15, 2002).

6. Jennifer Rutherford-McClure, Comment \& Note, To Donate or Not To Donate Your Organs: Texas Can Decide for You When You Cannot Decide for Yourself, 6 TEX. WESLEYAN L. REV. 241, 243 (2000) ("On average, three thousand people will die each year while waiting for an 
complicating the matter is the fact that not all organs are compatible with each potential recipient; there is a serious risk that a recipient's body will reject a transplanted organ. ${ }^{7}$ In addition, because people's organs grow as they get older, a donor must be close to the recipient in age, or at least stature, for the transplanted organ to "fit" properly. ${ }^{8}$ For these reasons, members of a patient's immediate family, especially siblings, are among the best potential organ donors. ${ }^{9}$ The ideal donor would, of course, be an identical twin. $^{10}$

Neither children," nor adults suffering from severe mental impairment, ${ }^{12}$ are permitted to make decisions regarding medical treatment

organ transplant. Currently, there are over fifty-eight thousand people waiting for transplants, but in 1997, only fifty-five hundred organs were donated." (emphasis added)).

7. Mark F. Anderson, Encouraging Bone Marrow Transplants from Unrelated Donors: Some Proposed Solutions to a Pressing Social Problem, 54 U. PITT. L. REV. 477, 482 (1993) ("A major risk in any organ transplant is that the immune system of the organ recipient wil! identify the transplanted tissue as a foreign invader and attempt to destroy it. This phenomenon is commonly called 'rejection.' Rejection can be reduced or even eliminated by requiring a very close match between the donor's tissue type and the recipient's."); see also MASS. GEN. HOSP. ORGAN Transplant TEam \& H.F. Pizer, ORgan Transplants 18 (1991) [hereinafter Organ TRANSPLANTS] ("When transplanted organs are rejected, it is because the recipient's immune system recognizes that the surface antigens on the replacement organ do not match his or her own surface antigens.").

8. ROBERT FINN, ORGAN TRANSPLANTS 52-53 (2000). Finn explains:

[One of the] factors that govem[s] whether a particular donor organ may be suitable for a particular recipient ... [is] its size in comparison to the recipient .... A heart from a 120-pound woman could not maintain the circulation of a 250-pound man. Conversely, a set of lungs from a large man would not be able to expand properly in the chest of a small womán.

Id.

9. R. GRANT STEEN \& JosePh MiRRo, JR., ChILDHOOD CANCER 158 (2000) ("If the patient has a sibling who is a perfect match, that sibling would be the best donor.").

10. See Marie Bakitas Whedon, Bone Marrow Transplantation 110 (1991) ("A patient lucky enough to have an identical twin may be a candidate for what is called a syngenic transplant. In this case, there is complete genetic identity at all histocompatibility loci.").

11. It is not entirely accurate to say that all children are deemed incompetent to make medical decisions. Many courts have recognized that so-called mature minors have the right to make such decisions for themselves. See, e.g., E.G. v. E.G., 549 N.E.2d 322, 327-28 (III. 1989) (holding that if "the minor is mature enough to appreciate the consequences of her actions, and ... the minor is mature enough to exercise the judgment of an adult, then the mature minor doctrine affords her the common law right to consent to or refuse medical treatment"). The Supreme Court has held that mature minors have the right to decide for themselves whether to have an abortion. Bellotti $\mathrm{v}$. Baird, 443 U.S. 622, 643 (1979) (plurality opinion) (holding that states cannot require a minor to obtain parental consent before obtaining an abortion if "she is mature enough and well enough informed to make her abortion decision ... independently"). Thus, the term "children" as used in this Note should be read as encompassing only those minors who are legally unable to tender consent to medical procedures on their own.

This Note does not purport to limit the rights of mature minors, nor to establish criteria for distinguishing mature from nonmature minors, accepting instead the already well-established legal framework for addressing such issues. See generally Wanda K. Mohr \& Sheila Suess Kennedy, The Conundrum of Children in the U.S. Health Care System, in 8 NURSING ETHICS 196 (2001) (discussing the gradual recognition of the right of mature minors to make health-care decisions for themselves).

12. It is not the purpose of this Note to propose a framework for determining when an adult's mental disabilities are sufficiently severe to warrant a finding of legal incompetence. Again, this 
for themselves; both groups generally depend on their legal guardians (most often, parent-guardians) to tender "proxy consent" for such treatment. ${ }^{13}$ The term "incompetents" is used throughout this Note to refer to those who, for reasons of age or mental defect, are legally incapable of tendering consent.

In recent years, the right of parent-guardians to consent to organ donation on behalf of their incompetent wards has been severely criticized by many academics. ${ }^{14}$ Several commentators, while not arguing for a prohibition on the practice, nonetheless regard it with great skepticism, ${ }^{15}$ or fail to reach any definite conclusions. ${ }^{16}$ Some articles ignore the constitutional dimension of the issue and focus instead on potential legislative responses. ${ }^{17}$

Note accepts the already existing, well-developed standards in this area. See, e.g., Stephen Billick et al., Competency To Consent to Hospitalization in the Medical Patient, 25 J. AM. ACAD. PSYCHIATRY \& L. 191 (1997) (discussing determinants of legal competency to consent to medical procedures); Marya E. Pollack \& Stephen B. Billick, Competency To Consent to Treatment, 70 PSYCHIATRIC Q. 303 (1999) (same).

13. See In re Spring, 405 N.E.2d 115, 121 (Mass. 1980) ("In the absence of consent or its equivalent, it has been common practice to seek the appointment of a guardian for an incompetent patient."); Parents United for Better Schs., Inc. v. Bd. of Educ., 646 A.2d 689, 691 (Pa. Commw. Ct. 1994) ("The principle that parental consent must be secured before medical treatment [is] provided is time honored .... Generally, it is for the parent in the first instance to decide what is actually necessary for the protection and preservation of the life of his or her child."); see also Dan Brock, What Is the Moral Authority of Family Members To Act as Surrogates of Incompetent Patients?, 74 MILBANK Q. 599, 599 (1996) (discussing the philosophical basis for the right of families to make important decisions on behalf of incompetent patients).

14. See, e.g., Russell Scott, The Terrible Imbalance: Human Organs and Tissues for Therapy -A Review of Demand and Supply, 9 J. CONTEMP. HEALTH L. \& POL'Y 139, 143 (1993) (questioning the "morality of removing tissues from children or others who lack capacity or whose consent is not free"); Cara Cheyette, Note, Organ Harvests from the Legally incompetent: An Argument Against Compelled Altruism, 41 B.C. L. REv. 465, 477 (2000). See generally Joel D. Kallich \& Jon F. Merz, The Transplant Imperative: Protecting Living Donors from the Pressure To Donate, 20 J. CORP. L. 139 (1995) (discussing the need for additional safeguards for potential donors when the recipient is a family member).

15. See, e.g., Jennifer L. Rosato, Using Bioethics Discourse To Determine When Parents Should Make Health Care Decisions for Their Children: Is Deference Justified?, 73 TEMP. L. REV. I, $57(2000)$ (arguing that in the context of organ donation by a minor, "assuming a parental conflict of interest is justified because a parent who is considering the benefits of donation to the ill child would be unable to consider fairly the risks and benefits to the donor child. Moreover, donation constitutes an extraordinary medical treatment because it is, by definition, nontherapeutic").

16. See, e.g., Howard S. Schwartz, Bioethical and Legal Considerations in Increasing the Supply of Transplantable Organs: From UAGA to "Baby Fae," 10 AM. J.L. \& MED. 397, 424-28, 437 (1985) ("There is no 'right' approach because different ethical theories lead to different results. Some approaches are ethically preferable because they further interests in fairness of resource allocation and individual autonomy, but are less efficient to administer. Others are less expensive financially, but contain other societal costs.").

17. See, e.g., Bryan Shartle, Comment, Proposed Legislation for Safely Regulating the Increasing Number of Living Organ and Tissue Donations by Minors, 61 LA. L. REV. 433, 438-44 (2001) (discussing the statutory right of minors under Louisiana law to consent to treatment for diseases and the general right of parents to overrule a minor's decision against treatment). 
Moreover, proxy consent has been found invalid by many courts. ${ }^{18}$ Those cases in which courts have found that parent-guardians do have the right to tender proxy consent are surprisingly terse and relatively cursory in their analyses. ${ }^{19}$

In this Note, I argue that the constitutional rights of children and mentally impaired persons (collectively, incompetents) are violated when the law fails to provide a mechanism through which proxy consent ${ }^{20}$ may be tendered for donation of a nonvital organ ${ }^{21}$ to an immediate family member. I further demonstrate that, in general, the Constitution accords parentguardians, ${ }^{22}$ and not judges, ultimate authority for determining whether such organ donation is appropriate. ${ }^{23}$

18. In re Richardson, 284 So. 2 d 185,187 (La. Ct. App. 1973) (holding, with regard to a seventeen-year-old retarded adolescent with the mental capacity of a three- or four-year-old, that "neither his parents nor the courts can authorize surgical intrusion on Roy for the purpose of donating one of his kidneys to his sister, Beverly"); In re Guardianship of Pescinski, 226 N.W.2d 180,182 (Wis. 1975) ("In the absence of real consent on his part, and in a situation where no benefit to him has been established, we fail to find any authority for the county court, or this court, to approve this operation."); see Curran v. Bosze, 566 N.E.2d 1319 (Ill. 1990) (declining to allow a bone marrow transplant where one parent consents, one parent objects, and the potential recipient is a half-brother to whom the potential donor has no significant relationship); see also Strunk v. Strunk, 445 S.W.2d 145, 151 (Ky. 1969) (Steinfeld, J., dissenting) (declaring that he was "unwilling to hold that the gates should be open to permit the removal of an organ from an incompetent for transplant, at least until such time as it is conclusively demonstrated that it will be of significant benefit to the incompetent").

19. See, e.g., Bonner v. Moran, 126 F.2d 121 (D.C. Cir. 1941) (noting in passing, without reasoning or analysis, that parents have the right 10 consent on behalf of their children to operations intended to benefit other family members); Hart v. Brown, 289 A.2d 386, 388 (Conn. Super. Ct. 1972) ("The court [in Strunk] held that a court of equity does have such power [to authorize transplants], applying also the 'doctrine of substituted judgment.' Therefore, this court is of the opinion that it has the power to act in this matter."); Strunk, 445 S.W.2d at 148-49 (stating without elaboration that "substantial evidence" indicates that the transplant would be in the "best interest" of the incompetent donor while incongruously claiming to apply the doctrine of "substituted judgment").

20. I use the term "proxy consent" throughout this Note to refer to consent tendered by some third party on behalf of an individual legally incapable of offering or refusing such consent on his own behalf.

21. The phrase "nonvital organs" refers to kidneys, portions of the liver, and bone marrow. Although liver and bone marrow regenerate after donation while a kidney does not, the risks associated with donation of any of these organs are small. See infra Part I.

22. The term "parent-guardian" should be read as encompassing grandparent-guardians as well. See Moore v. City of E. Cleveland, 431 U.S. 494, 505 (1977) ("Decisions concerning child rearing,... [which are] entitled to constitutional protection, long have been shared with grandparents or other relatives who occupy the same household-indeed who may take on major responsibility for the rearing of the children.").

23. I add the qualifier "in general" because, as discussed later in this Note, see infra notes 107,110-111 and accompanying text, this second thesis does not extend to the rare case where the potential donor was a once-competent mature minor or adult who has since lapsed into legal incompetency.

Moreover, the topic of this Note should not be confused with the debate over whether parents of anencephalic infants should be able to consent to the donation of their children's organs. Because parental consent to organ donation on behalf of anencephalic infants raises moral issues above and beyond those arising from the matters at issue in this Note, that practice is not considered here. See In re T.A.C.P., 609 So. 2d 588 (Fla. 1992) (holding that parents may not 
Part I of this Note examines the available statistics regarding organ donation and explores the safety of such procedures. In particular, it demonstrates that organ donation poses only small risks to a donor's physical and psychological well-being. Part II studies proxy consent from the perspective of children and mentally impaired individuals, arguing that an absolute prohibition on proxy consent for organ donation-whether legislatively or judicially imposed-would violate their right to bodily integrity and run afoul of the Equal Protection Clause.

With the principle established that some mechanism for proxy consent must exist, Part III studies the matter from the perspective of parentguardians. My ultimate conclusion is that the decision of parent-guardians to tender or withhold proxy consent may not constitutionally be secondguessed by judges. This conclusion can be reached either through a conservative approach or through a more radical departure from common assumptions in this area.

First, I examine the rights of parent-guardians, accepting arguendo the traditional assumption that they are bound to act in the best interests of their wards. Because the decision as to whether organ donation is in the best interests of an incompetent is based primarily on value judgments and subjective, nonquantifiable factors, I assert that it falls squarely within the constitutionally protected range of discretion of parent-guardians, and may not be reviewed by courts.

Ultimately, however, I reject the traditional assumption, arguing instead that parents need not make this decision based solely on the prospective donor's best interests. Parent-guardians have the right to take into account other factors, such as the demands of morality and the best interests of the family as a whole. As a practical matter, it is irrelevant which of these arguments one accepts, because the family's decision in either case is unreviewable. Nonetheless, I argue that this latter framework is more consistent with recognizing the dignity and humanity of both children and the mentally impaired.

Part IV addresses a potential ethical dilemma arising from the right of parent-guardians to tender proxy consent for organ donation-the phenomenon of parents conceiving children specifically to be organ donors. This Part examines how the frequency and success rate of such endeavors are greatly enhanced by emerging reproductive and genetic technologies. It concludes, however, that these consequences are not legitimate grounds for opposing this Note's theses regarding proxy consent. Part V concludes.

This Note does not pretend to offer a complete solution to this nation's chronic organ shortage. Instead, this Note attempts to mitigate, however

have an anencephalic infant declared brain-dead, absent cessation of circulatory and respiratory functions, for the purpose of having her organs harvested). 
slightly, the harsh effects of this shortage by arguing for recognition of the right of children and mentally impaired individuals to donate their organs to immediate family members, and the right of parent-guardians to consent to such donation. Awareness of such rights will help ensure that human life is not unnecessarily extinguished by ill-informed legislative policies or judicial determinations, and that the dignity of those unable to act on their own behalf is respected. ${ }^{24}$

\section{ORGAN DONATION: STATISTICS AND RISKS}

Every year, the number of organ transplants from living donors continues to increase. ${ }^{25}$ Between 1988 and 2000, close to 140,000 kidney transplants were conducted; over 41,000 of these procedures involved kidneys from living donors. ${ }^{26}$ During the same period, over 46,000 liver transplants occurred, with over 1000 involving donations from live donors. ${ }^{27}$ Since 1987 , between 60,000 and 70,000 bone marrow transplants were made possible by living donation. ${ }^{28}$

Siblings, including minor siblings, constitute a sizable pool of living organ donors. Since 1996, 109 children have received kidney transplants, and four children have received liver transplants, from either a full or halfsibling. ${ }^{29}$

The supply of organs available for transplantation is still dwarfed by demand, however. As of January 15, 2002, there were 50,803 patients waiting to receive kidneys and 18,744 in need of livers; 1849 of these patients were under the age of eighteen. ${ }^{30}$ Nearly half of the people on the waiting list were of ethnicities other than Caucasian. ${ }^{31}$ At any given time,

24. In McFall v. Shimp, 10 Pa. D. \& C.3d 90 (C.P. 1978), the court affirmed:

For our law to compel defendant to submit to an intrusion of his body would change every concept and principle upon which our society is founded. To do so would defeat the sanctity of the individual, and would impose a rule which would know no limits, and one could not imagine where the line would be drawn.

Id. at 91. This Note addresses situations where the potential donor-due to age or mental infirmity-is unable to make a determination on her own as to whether to donate.

25. See United Network for Organ Sharing, supra note 5.

26. $I d$.

27. $1 d$.

28. Nat'1 Marrow Donor Program, Marrow Donation, at http://www.marrow.org/FAQS/ marrow_faqs.html (last visited Jan. 15, 2002).

29. United Network for Organ Sharing, Transplants, at http://www.unos.org/Newsroom/ critdata_transplants_relation.htm (last visited Jan. 15, 2002).

30. United Network for Organ Sharing, Waiting List, at http://www.unos.org/Newsroom/ critdata_wait.htm (last visited Jan. 15, 2002).

31. Of the nearly 85,000 people waiting for an organ transplant, over 21,000 were black, over 11,000 were Hispanic, and close to 4700 were of other ethnicities. Id. Removing barriers to donation by family members is particular important to minorities because it is more difficult to find compatible organs from unrelated donors. See Ian Ayres et al., Unequal Racial Access to Kidney Transplantation, 46 VAND. L. REV. 805, 808-09 (1993) (discussing how it is difficult for African Americans to be matched with compatible unrelated donors because "antigens are 
over 3000 patients are looking for a compatible bone marrow donor in the National Bone Marrow Program Registry. ${ }^{32}$

As the above statistics indicate, transplant procedures have become fairly commonplace and pose little risk to donors. Kidney donation, for example, is for the most part safe and painless. " Under local anesthesia a long thin tube, called a catheter, is introduced into the artery in the groin, and a special dye is injected that permits the radiologist to examine the kidney[s'] circulation." ${ }^{34}$ The physician then X-rays both kidneys; the dye allows her to determine which has fewer blood vessels attached to it. Finally, while the patient is under general anesthesia,

[a]n incision is made over the tip of the twelfth or last rib, and a portion of the bone is removed. The donor kidney is carefully exposed, its blood vessels and ureter are identified, and when all is ready, it is separated from the blood supply and removed from the body .... [T] he donor's wound will be sewn together and he or she will be allowed to wake up. ${ }^{35}$

Liver transplants are similarly safe because only a portion of the donor's liver is removed. ${ }^{36}$ Due to the liver's regenerative capacity, both the transplanted portion as well as the donor's own liver are able to grow into whole, fully functioning organs." "More than 100 living related liver

distributed differently among racial groups" and "[w]hites donate almost ninety percent of kidneys in the United States," meaning "white patients are more likely to have antigens that match those on donated kidneys").

32. Nat'I Marrow Donor Program, About the National Marrow Donor Program, at http://www.marrow.org/NMDP/about_nmdp_idx.html (last visited Jan. 18, 2002).

33. ORgan TransPlants, supra note 7, at 151 ("Serious complications are extremely rare... The most common problem, which is relatively minor, is difficulty in passing urine immediately after surgery."). One study reveals that out of 40,000 transplant procedures, roughly twenty donors died $(0.05 \%)$. T.E. Starzl, Living Donors, 19 TranSPLANTATION PROC. 174, 174 (1987). In the words of one court:

The short-range risk to a donor is negligible ... . [T] he surgical risk is no more than the risk of the anesthesia. The operative procedure would last about two and one-half hours. There would be some minor postoperative pain but no more than in any other surgical procedure. The donor would be hospitalized for about eight days and would be able to resume normal activities in thirty days. Assuming an uneventful recovery, the donor would thereafter be restricted only from violent contact sports. She would be able to engage in all of the normal life activities of an active young girl.

Hart v. Brown, 289 A.2d 386, 389 (Conn. Super. Ct. 1972).

34. ORGAN TRANSPLANTS, supra note 7, at 150 .

35. Id. at 151 .

36. FINN, supra note 8 , at 226 ("[T]he liver is a very large organ with several segments. Surgeons have discovered ways to remove only a single segment.... [T] he small portion of the liver transplanted into a child, for example, will grow with the child, and will remain completely functional and normal in size.").

37. Id. (" $[\mathrm{L}] \mathrm{iver}$ tissue regenerates. That means that the remaining portion of the donor's liver will-within just a few months—expand to make up the portion that's missing."). 
transplantations have been performed world wide, and donor mortality or major morbidity has not been reported." 38

Bone-marrow transplants are the most effective form of treatment for leukemia and over thirty other types of blood diseases. ${ }^{39}$ They, too, are relatively uncomplicated.

Donating bone marrow involves little risk and only a small amount of discomfort. The harvesting of bone marrow generally takes place ... with the donor under general anesthesia. A long needle is inserted into the hip bone, which has a large supply of bone marrow. Several bone punctures on each hip will be required to remove the necessary amount of marrow. ${ }^{40}$

This procedure poses no serious health risks, even for child donors. According to one study based on twenty years of data involving bone marrow donations by children less than four years old, such "surgery can be safely performed with minimal risk[;] . . neither age nor size should be a contraindication to the donation of bone marrow." 41

Organ donation is also virtually free of adverse long-term consequences for donors. Kidney donors do not have a heightened risk for renal failure later in life. ${ }^{42}$ Because donated liver and bone marrow naturally regenerate, their donation entails essentially no long-term ramifications. ${ }^{43}$

Notwithstanding the high level of physical safety of donation procedures, it has been argued that donors often suffer adverse psychological consequences from their experience. One commentator summarizes a study on children who donated bone marrow to siblings by

38. Xavier Rogiers \& Christoph E. Broelsch, Surgical Aspects, in LivER TRANSPLANTATION 143, 149 (James Neuberger \& Michael R. Lucey eds., 1994); see also FinN, supra note 8, at 228 (" $[\mathrm{A}]$ lthough the donor experiences major surgery, the risks are relatively small, and the recovery period is usually about the same as for kidney donors.").

39. H. Gilbert Welch \& Eric B. Larson, Cost Effectiveness of Bone Marrow Transplantation in Acute Non-Lymphocytic Leukemia, 321 NEW ENG. J. MED. 807 (1989).

40. FinN, supra note 8, at 113.

41. Leonard A. Valentino et al., Bone Marrow Donation by Small Children, in BONE MARROW TRANSPlantation 389, 393 (Robert Peter Gale \& Richard E. Champlin eds., 1989).

42. THE MULT-ORGAN DONOR 189 (Robert S.D. Higgins et al. eds., 1997) (" Based on more than 20 long-term studies of kidney donors, consensus among the transplant community is that well-selected donors incur no increased risk of ESRD [end stage renal disorder] over the general population."); see also Hart v. Brown, 289 A.2d 386, 389 (Conn. Super. Ct. 1972) ("[T]he risk to the donor is such that life insurance actuaries do not rate such individuals higher than those with two kidneys. The only real risk would be trauma to the one remaining kidney, but testimony indicated that such trauma is extremely rare in civilian life.").

43. Marrow removed for transplantation "is replaced by the body within 4 to 6 weeks, so there is no significant adverse risk to the donor. Specifically, there is no increased risk of infection or susceptibility to infection since the remainder of the marrow is more than adequate to protect the donor." ORGAN TRANSPLANTATION 210 (Barbara A. Helene Williams et al. eds., 1991). In a study of 3290 bone-marrow transplants, $0.27 \%$ involved complications, and none resulted in deaths or "permanent sequelae." Id. at 211 . On the regeneration of liver tissue, see supra notes 36-37. 
claiming that "fully one-third of children whose siblings were bone marrow recipients suffered from signs of post traumatic stress syndrome." ${ }^{44}$ The commentator goes on to point out, however, that " $[t]$ his was true for both siblings who donated and siblings who did not donate." ${ }^{45}$ That is, being an organ donor did not increase the likelihood that a child with a sibling in need of a transplant would suffer psychological harm. Moreover, while the commentator claims that the study demonstrates that children who donated were more "withdrawn, anxious, depressed and had a lower sense of self esteem," ${ }^{46}$ the study in fact concluded that "[d]onors seem to cope with the stress by channeling their efforts into their school work: parents and teachers reported that they were generally more mature and showed more leadership potential." 47

It has also been claimed that kidney donors are at risk for psychological trauma when the transplant is unsuccessful. "[B]ecause the rejection rate for even closely matched kidneys can run as high as twenty percent, kidney donors... may feel that they underwent major surgery and gave up a kidney for nothing." ${ }^{48}$ The UCLA study cited for this proposition, however, found that only $10-20 \%$ of donors surveyed suffered negative psychological consequences. Moreover, the study was based on a questionnaire mailed to a small group of donors. ${ }^{49}$

More extensive studies have reached the opposite conclusion. For example, in a study of 451 living kidney donors with a $92 \%$ response rate, "[a]lmost all of them felt that the donation affected their lives in a positive way.... Of particular interest was that only three $(0.8 \%)$ of the donors regretted the donation, two were undecided $(0.5 \%)$, and thus almost $99 \%$ reported that they did not regret their decision." 50

Thus, claims that organ donation is psychologically harmful to donors are unsupported, and even contradicted, by research results. Moreover, donor support programs, such as the successful program at the Hospital for Sick Children in Ontario, Canada, can dramatically reduce even the potential for undesirable psychological consequences, especially when geared to pediatric or mentally impaired donors. ${ }^{51}$

44. Cheyette, supra note 14 , at 477.

45. Id.

46. Id at 478 .

47. Philip Cohen, Donors' Dread: Why Do Children Who Help a Sick Sibling End Up Depressed?, NEw SCIENTIST, Aug. 23, 1997, at 20.

48. Cheyette, supra note 14 , at 479.

49. Deane L. Wolcott et al., Psychological Adjustment of Adult Bone Marrow Transplant Donors Whose Recipient Survives, 41 TRANSPLANTATION 484, 484 (1986). The reliability of such psychological self-assessments is unclear.

50. Ingela Fehrman-Ekholm et al., Kidney Donors Don't Regret, 69 TRANSPLANTATION 2067,2069 (2000).

51. The Experience and Preparation of Pediatric Sibling Bone Marrow Donors, 27 SoC. WORK HEALTH CARE 89, 89 (1998) ("The donors are engaged in age-appropriate medical play and are encouraged to discuss their feelings and concerns about their role. . . Thus far, $97.5 \%$ 
Having examined the procedures involved in organ donation, as well as the small physical and psychological risks donation poses, it is now appropriate to examine the right of all people, including children and mentally impaired persons, to donate nonvital organs when necessary to save the lives of family members.

\section{The Rights OF ChILdREN AND THE MENTALLy IMPAIRED}

As noted earlier, several courts have ruled that parent-guardians may not tender proxy consent for organ donation on behalf of children or mentally impaired adults. ${ }^{52}$ This Part demonstrates that such blanket restrictions are unconstitutional. It begins by showing that competent adult patients have the constitutional right to consent on their own behalf to organ donation. It then argues that it would violate the Equal Protection Clause for a legislature or court to prohibit proxy consent for organ donation by incompetents, or to establish standards for permitting proxy consent that in practice would never result in an actual donation. This Part concludes by demonstrating how such a blanket prohibition undermines the fundamental dignity of children and the mentally impaired as human beings.

\section{A. The Right of Competent Adults To Donate Organs to Immediate Family Members}

No case directly supports the existence of a constitutional right to donate one's organs to immediate family members because no state has ever tried to outlaw the practice. Although the sale of organs may be, and is, prohibited consistent with the Constitution, ${ }^{53}$ it is not clear that a ban on altruistic gifts would survive constitutional scrutiny. There are three constitutional bases for the right to donate organs, especially to family members: (1) the positive right to bodily integrity as embodied in Roe $v$. Wade $^{54}$ and informed consent cases, (2) the more generalized right to

have rated the program very helpful."); see also K.H. Schultz et al., Comparison of Quality of Life and Family Stress in Families of Children with Living-Related Liver Transplants Versus Families of Children Who Received a Cadaveric Liver, 33 TRANSPLANTATION PROC. 1496, 1497 (2001) (calling for the "provision of both pre- and postoperative psychological support, not only for the child receiving the transplant, but also for his whole family").

52. See supra note 18 .

53. 42 U.S.C. $\$ 274$ e(a) (1994) ("It shall be unlawful for any person to knowingly acquire, receive, or otherwise transfer any human organ for valuable consideration for use in human transplantation if the transfer affects interstate commerce."). No cases exist wherein a defendant accused of organ trafficking argued that the statute prohibiting the sale of organs was unconstitutional. The commercial aspect of organ selling removes such behavior from constitutionally protected zones of privacy.

54. 410 U.S. 113 (1973). 
privacy established in Griswold v. Connecticut, ${ }^{55}$ and (3) the protection of "fundamental" rights under the Fourteenth Amendment's Due Process Clause as articulated in Palko v. Connecticut. ${ }^{56}$

Well-established precedent on both the state $^{57}$ and federal ${ }^{58}$ levels clearly defines the constitutionally protected negative right to bodily integrity, which prohibits the government from physically intruding into people's bodies absent a compelling justification. Other cases, however, recognize a positive right to bodily integrity as well, broad enough to encompass the right to donate an organ. For instance, the United States Supreme Court has held, "No right is held more sacred, or is more carefully guarded by the common law, than the right of every individual to the possession and control of his own person." ${ }^{59}$ State supreme courts have followed suit-"Every human being of adult years and sound mind has a right to determine what shall be done with his own body." 60

The rhetoric in modern abortion cases concerning a woman's right to control her own body is broad enough to support the right to donate organs, as it encompasses much more than the right to terminate a pregnancy. ${ }^{61}$ For instance, in Young Women's Christian Ass'n v. Kugler, a pre-Roe abortion case, a district court adopted the plaintiff's contention that "the

55. 381 U.S. 479 (1965).

56. 302 U.S. 319 (1937).

57. Superintendent of Belchertown State Sch. v. Saikewicz, 370 N.E.2d 417, 423 (Mass. 1977) (recognizing "the right of a patient to preserve his or her right to privacy against unwanted infringements of bodily integrity in appropriate circumstances").

58. Federal cases discussing the negative right to bodily integrity have largely addressed the reasonableness under the Fourth Amendment of searches involving penetrations into the body. In such cases, the rights to privacy and bodily integrity are weighed against society's interest in obtaining potentially incriminating evidence. See, e.g., Winston v. Lee, 470 U.S. 753, 766 (1985) (" $[T]$ he intrusion on respondent's privacy interests entailed by the operation [to have a potentially incriminating bullet removed from his body] can only be characterized as severe. On the other hand, although the bullet may turn out to be useful to the Commonwealth in prosecuting respondent, the Commonwealth has failed to demonstrate a compelling need for it."); Schmerber v. California, 384 U.S. 757, 769-70 (1966) (holding that the Constitution restricts "searches involving intrusions beyond the body's surface. The interests in human dignity and privacy which the Fourth Amendment protects forbid any such intrusions on the mere chance that desired evidence might be obtained"); Rochin v. Califomia, 342 U.S. 165, 172 (1952) ("[T]he proceedings by which this conviction was obtained ... shock[] the conscience. Illegally breaking into the privacy of the petitioner, the struggle to open his mouth and remove what was there, the forcible extraction of his stomach's contents ... is bound to offend even hardened sensibilities.").

59. Union Pac. Ry. Co. v. Botsford, 141 U.S. 250, 251 (1891) (refusing to compel a personal injury plaintiff to undergo a pretrial medical examination).

60. Schloendorff v. Soc'y of N.Y. Hosp., 105 N.E. 92, 93 (N.Y. 1914), overruled on other grounds by Bing v. Thunig, 143 N.E.2d 3, 9 (N.Y. 1957).

61. See, e.g., Johnson v. San Jacinto Junior Coll., 498 F. Supp. 555, 574 (S.D. Tex. 1980) (describing the right to privacy as "encompass[ing] decisions regarding the integrity and autonomy of one's body"); Fla. Dep't of Health v. N. Fla. Women's Health \& Counseling Serv., Inc., Nos. 1D00-1983, 1D00-2106, 2001 Fla. App. LEXIS 1217, at $* 26$ (Fla. Dist. Ct. App. Feb. 9,2001 ) ("The individual right at issue here is a woman's right to control her body and her future.") (internal quotation marks and citation omitted); People v. Nixon, 201 N.W.2d 635, 640 n.17 (Mich. Ct. App. 1972) ("There can be no question as to the right of the woman to possess and control her body as she sees fit."). 
Constitution protects the right of an individual to control the use and function of his or her body without unreasonable interference from the state." ${ }^{2}$

Indeed, the factors that led the Supreme Court in Roe v. Wade $e^{63}$ to conclude that the right to privacy includes the right to an abortion also exist with regard to organ donation to immediate family members. ${ }^{64}$ Just as " [m]aternity, or additional offspring, may force upon the [pregnant] woman a distressful life and future," ${ }^{65}$ so too can the sickness or death of an immediate family member cause a distressful life and future for an eligible donor. The anguish of a lost child can end a marriage; the loss of a parent can be emotionally and financially devastating. ${ }^{66}$

For both would-be organ donors and pregnant women contemplating abortion, "[p]sychological harm" may result from a prohibition on their contemplated acts, and their " [m]ental and physical health may be taxed." 67 Finally, for both groups, such prohibitions would cause severe "distress, for all concerned." ${ }^{68}$ For women seeking an abortion, it would stem from "the unwanted child, and...the problem of bringing a child into a family already unable, psychologically and otherwise, to care for it" ; ${ }^{69}$ for potential organ donors, it would result from the preventable death of a family member. Organ donation to immediate family members, like abortion, is one of "a person's most basic decisions about family," and one of "the most intimate and personal choices a person may make in a lifetime, [a choice] central to personal dignity and autonomy." 70

Moving beyond the abortion context, many informed consent cases speak not only of the right to refuse medical treatment, but of a more generalized right to control one's body. ${ }^{71}$ Indeed, the same considerations

62. 342 F. Supp. 1048, 1066 (D.N.J. 1972), aff d, 493 F.2d 1402 (3d Cir. 1974).

63. 410 U.S. 113 (1973).

64. Indeed, it is because these factors apply with particular force when the prospective recipient is a family member that the theses of this Note are restricted to such cases.

65. Roe, 410 U.S. at 153.

66. GeORGE M. BuRnell \& Adrienne L. Burnell, Clinical Management of BEREAVEMENT 51, 79 (1989) (discussing the psychological effects of the death of a parent on children and the death of a child on parents).

67. Roe, 410 U.S. at 153.

68. Id.

69. Id.

70. Planned Parenthood v. Casey, 505 U.S. 833, 849, 851 (1992).

71. E.g., Gray v. Romeo, 697 F. Supp. 580, 585 (D.R.I. 1988) (recognizing the right of the individual to "control fundamental medical decisions that affect his or her own body. This right, whether described as the principle of personal autonomy, the right of self-determination, or the right of privacy, is properly grounded in the liberties protected by the Fourteenth Amendment's due process clause"); Tillman v. Detroit Receiving Hosp., 360 N.W.2d 275, 277 (Mich. Ct. App. 1984) ("The privacy right encompasses the right to make decisions conceming the integrity of one's body."); Penick v. Christensen, 912 S.W.2d 276, 285 (Tex. App. 1995) (concluding that the state and federal constitutions "protect[] zones of privacy [that] impose restraints on unwarranted governmental interference in individual autonomy rights, that is, the freedom to determine for oneself whether to undergo certain experiences or to perform certain acts"); see also Rogers $v$. 
that lead courts to place so much emphasis on informed consent also apply to organ donation:

[M]edical treatment decisions are, to an extraordinary degree, intrinsically personal. It is the individual making the decision, and no one else, who lives with the pain and disease, ... who must undergo or forego the treatment,... [and] who, if he or she survives, must live with the results of that decision. One's health is a uniquely personal possession. The decision of how to treat that possession is of a no less personal nature. ${ }^{72}$

The decision to donate an organ raises these concerns because, like a therapeutic operation, it requires intrusion into the body. Indeed, in many ways it represents an even more fundamental decision, because the harm from not donating is visited upon someone else. It may be extremely difficult for an individual who does not donate to "live with the results of that decision." 73

The right to donate organs can also be derived directly from the right to privacy recognized in Griswold v. Connecticut. ${ }^{74}$ As the Montana Supreme Court declared, "Griswold and other privacy decisions can be justified only on the presumption that [certain] decisions ... are so intimate and personal that people must in principle be allowed to make these decisions for themselves, consulting their own preferences and convictions, rather than having society impose its collective decision on them." 75 Organ donation seems to fall within the scope of the "decisions concerning one's body" that are "protected by the federal constitutional right of privacy." 76

Finally, organ donation can be seen as a fundamental right directly protected by the Due Process Clause of the Fourteenth Amendment. ${ }^{77}$ The Supreme Court has articulated two standards for determining whether a right is sufficiently "fundamental" to be protected by the Due Process

Okin, 478 F. Supp. 1342, 1368 (D. Mass. 1979) ("Each of us has a basic right to care for our bodies subject to reasonable regulations ....") (internal quotation marks omitted).

72. Armstrong v. State, 1999 MT 261, I 54, 989 P.2d 364, 378 (quoting Andrews v. Ballard, 498 F. Supp. 1038, 1047 (S.D. Tex. 1980)).

73. Id.

74. 381 U.S. 479 (1965).

75. Armstrong, 1999 MT 261, If 47, 989 P.2d at 377 (quoting RONALD DWORKIN, LiFE's DOMINION: AN ARGUMENT ABOUT ABORTION, EUTHANASIA, AND INDIVIDUAL FREEDOM 106 (First Vantage Book 1994) (1993)); see also Thor v. Superior Court, 855 P.2d 375, 380 (Cal. 1993) (en banc) ("[O]ver his own body and mind, the individual is sovereign." (quoting JOHN STUART MILL, ON LIBERTY 13 (1859))).

76. In re Conroy, 486 A.2d 1209, 1222 (N.J. 1985) (allowing the nephew-guardian of a terminally ill patient with severe physical and mental impairments to have her feeding tube removed).

77. The Due Process Clause of the Fourteenth Amendment provides, "[N]or shall any state deprive any person of life, liberty, or property, without due process of law." U.S. CONST. amend. XIV, \& 1 . 
Clause-it must be either "implicit in the concept of ordered liberty," 78 or it must be "so rooted in the traditions and conscience of our people as to be ranked as fundamental." 79 The right to do whatever one can, without violating the rights of others, to save the life of a family member, especially when the required act involves such an intimate, personal gift, seems sufficiently "fundamental" to warrant heightened constitutional protection. Perhaps the greatest testimony to this point is the fact that, as noted earlier, no state has ever taken steps to prohibit the practice.

Whether one wishes to draw analogies to the abortion cases, informed consent cases, or general privacy cases, or even consider the issue sui generis, organ donation to family members falls within "the private realm of family life which the state cannot enter." ${ }^{80}$ Although no court has yet faced the need to articulate such a right, it demands constitutional recognition.

\section{B. Equal Protection}

Even if, as argued in the previous Section, competent adults enjoy the constitutional right to donate organs to family members, this does not necessarily mean that the right should be extended to children and the mentally impaired. To understand why even members of these groups possess such a right, one must begin by looking to case law in an area in which the rights of the mentally impaired have long been disregardedsterilization.

Of all the states in the union, California has historically had one of the poorest records of respecting the reproductive liberties of those regarded by the state as "feeble-minded." ${ }^{81}$ By 1927, it had performed more than 5000 involuntary and compulsory sterilizations, which at the time was "four times as many as ha[d] been performed for eugenic reasons, in government

78. Palko v. Connecticut, 302 U.S. 319, 325 (1937), overruled on other grounds by Benton v. Maryland, 395 U.S. 784, 794 (1969). Initially, Palko was a benchmark for determining whether particular guarantees of the Bill of Rights were "incorporated" through the Fourteenth Amendment as binding on the states. See, e.g., Duncan v. Louisiana, 391 U.S. 145, 148-49 (1968) (recognizing that "[t]he test for determining whether a right extended by the Fifth and Sixth Amendments... is also protected against state action by the Fourteenth Amendment" is the Palko standard, as cited by subsequent cases). Palko has since been reinterpreted as a general test for determining whether a substantive right, whether or not mentioned in the Bill of Rights, must be respected by the states. See Roe v. Wade, 410 U.S. 113, 152 (1973) ("[O]nly personal rights that can be deemed 'fundamental' or 'implicit in the concept of ordered liberty' are included in this [Fourteenth Amendment] guarantee of personal privacy.") (citation omitted).

79. Roe, 410 U.S. at 174 (quoting Snyder v. Massachusetts, 291 U.S. 97, 105 (1934)).

80. Prince v. Massachusetts, 321 U.S. 158, 166 (1944).

81. Act of May 17, 1917, ch. 489, $\S 1,1917$ Cal. Stat. 571. 
institutions, in all the rest of the world together." ${ }^{82}$ Motivated in large part to break from this history, ${ }^{83}$ the state legislature in 1979 repealed the last remaining compulsory sterilization statute ${ }^{84}$ and simultaneously amended section 2356(d) of the state probate code to read, "No ward or conservatee may be sterilized under the provisions of this division." ${ }^{85}$ Under the resulting legislative scheme, there was no mechanism through which an individual legally incapable of offering consent could be sterilized.

In Conservatorship of Valerie N., a mother and stepfather sought to have their mentally impaired twenty-nine-year-old daughter Valerie, a victim of Down's Syndrome, sterilized on the ground that a "pregnancy would cause psychiatric harm" to her. ${ }^{86}$ The probate court had rejected their petition, relying on section 2356(d) of the California Probate Code, as well as the repeal of the compulsory sterilization statutes. The state supreme court agreed that the probate court had correctly interpreted applicable state law, ${ }^{87}$ but held section 2356(d) unconstitutional as applied to Valerie and others similarly situated. ${ }^{88}$

The court found that the statute touched upon Valerie's right to privacy, and invalidated it on both due process and equal protection grounds. ${ }^{89}$ The statute violated the Due Process Clause by infringing on a fundamental freedom without a compelling state interest. As the court noted, "If the state withholds from her the only safe and reliable method of contraception suitable to her condition, it necessarily limits her opportunity for habilitation and thereby her freedom to pursue a fulfilling life." ${ }^{90}$ Because the exercise of her fundamental right to sterilization would be in Valerie's best interests, the state could not erect a statutory scheme that failed to provide any opportunity for her to take advantage of it.

More pertinent to this Note, however, is the other basis on which the statute was invalidated-the Equal Protection Clause. The court ruled that section 2356(d) prevented Valerie's parents "from making, and Valerie from obtaining the advantage of, the one choice that may be best for her, and which is available to all women competent to choose-contraception

82. Comment, Constitutional Law-Sterilization of Defectives, 1 S. CAL. L. REv. 73, 74 n.5 (1927) (quoting Paul Popenoe, Eugenic Sterilization in California, 13 J. SOC. HYGIENE 257, 257 (1927)).

83. See Maxon v. Superior Court, 185 Cal. Rptr. 516, 520 (Ct. App. 1982).

84. Act of Sept. 18, 1979, ch. 730, \& 156.5, 1979 Cal. Stat. 2540 (repealing former section 7254 of the California Welfare and Institutions Code); Act of Sept. 10, 1979, ch. 552, § 1, 1979 Cal. Stat. 1762 (same).

85. Cal. Prob. Code $\S 2356$ (d) (West 1991).

86. 707 P.2d 760, 763 (Cal. 1985).

87. Id. at 771 .

88. Id. at $771-72$.

89. Id. at 773 (" [W] hether analyzed under due process or equal protection principles, the issue is whether withholding the option of sterilization as a method of contraception to this class of women is constitutionally permissible.").

90. Id. 
through sterilization." 91 The court went on to note that section 2356(d) "denied incompetent women the procreative choice that is recognized as a fundamental, constitutionally protected right of all other adult women." ${ }^{92}$ It acknowledged:

[E]lection of the method of contraception to be utilized, or indeed whether to choose contraception at all, cannot realistically be deemed a "choice" available to an incompetent since any election must of necessity be made on behalf of the incompetent by others. The interests of the incompetent which mandate recognition of procreative choice as an aspect of the fundamental right to privacy and liberty do not differ from the interests of women able to give voluntary consent to this procedure, however. ${ }^{93}$

Put another way, the right to choose sterilization is a component of a woman's reproductive liberty. A woman does not lose the right to be sterilized simply because she is incompetent; although her condition prevents her from exercising this right herself, the Constitution requires that someone be able to do so for her. If no such proxy consent mechanism exists, she is deprived of the benefits of the exercise of this constitutional right. Prohibiting the guardians of an incompetent from consenting to sterilization on her behalf, while permitting a competent woman to consent to sterilization, violates the Equal Protection Clause, because " $[a] n$ incompetent developmentally disabled woman has no less interest in a satisfying or fulfilling life free from the burdens of an unwanted pregnancy than does her competent sister." ${ }^{94}$ Other courts have since come to the same conclusion on similar grounds. ${ }^{95}$

This doctrine has also been applied in cases where courts have found that parent-guardians may decline lifesaving treatment on behalf of permanently vegetative patients. Again, such proxy consent is the only way for comatose patients to exercise the right to decline treatment recognized in the case of competent patients: ${ }^{96}$

91. Id. at 771 (emphasis added).

92. Id. at 772 .

93. Id.

94. Id. at 773 .

95. In re A.W., 637 P.2d 366, 369 (Colo. 1981) ("The procreative alternatives available to competent aduits must also extend where possible to individuals who are not mentally competent to make the choice for themselves."); In re Grady, 426 A.2d 467, 475 (N.J. 1981) ("The right to choose among procreation, sterilization and other methods of contraception is an important privacy right of all individuals. Our courts must preserve that right. Where an incompetent person lacks the mental capacity to make that choice, a court should ensure the exercise of that right on behalf of the incompetent in a manner that reflects his or her best interests." ).

96. On the right of competent patients to refuse treatment, see In re Quinlan, 355 A.2d 647

(N.J. 1976). Regarding lifesaving medical treatment, Quinlan held:

[T]he individual's right to privacy grows as the degree of bodily invasion increases and the prognosis dims. Ultimately there comes a point at which the individual's rights 
If a putative decision by Karen [a woman in a permanently vegetative state] to permit this non-cognitive, vegetative existence to terminate by natural forces is regarded as a valuable incident of her right of privacy, as we believe it to be, then it should not be discarded solely on the basis that her condition prevents her conscious exercise of the choice. The only practical way to prevent destruction of the right is to permit the guardian and family of Karen to render their best judgment, subject to the qualifications hereinafter stated, as to whether she would exercise it in these circumstances.... It is for this reason that we determine that Karen's right of privacy may be asserted in her behalf, in this respect, by her guardian and family under the particular circumstances presented by this record. ${ }^{97}$

Thus, although a mentally impaired adult cannot choose on her own behalf to donate organs, she nonetheless has a constitutionally protected right, under certain circumstances, to have that choice made for her. ${ }^{98}$

The Wisconsin Supreme Court, in In re Guardianship of Eberhardy, rejected such reasoning, holding that the parent-guardians of a severely retarded girl could not petition the court to have her sterilized..$^{99}$ It held that only the legislature could authorize the use of proxy consent for sterilization because "a court is not an appropriate forum for making policy in such a sensitive area." ${ }^{100}$ In so ruling, the court disregarded the fact that it was dealing with a fundamental right; whether or not to allow citizens, including legally incompetent citizens, to exercise such rights should not be a matter of legislative policy. As the Supreme Court has explained:

overcome the State interest. It is for that reason that we believe Karen's choice [to decline feeding tubes], if she were competent to make it, would be vindicated by the law.

Id. at 664 .

97. Id. (holding that the parent-guardian of a patient in a permanently vegetative state may exercise that patient's right to decline medical treatment, even where such treatment is necessary to preserve her life); see also Superintendent of Belchertown State Sch. v. Saikewicz, 370 N.E.2d 417,423 (Mass. 1977) ("We take the view that the substantive rights of the competent and the incompetent person are the same in regard to the right to decline potentially life-prolonging treatment. The factors which distinguish the two types of persons are found only in the area of how the State should approach the preservation and implementation of the rights of an incompetent person and in the procedures necessary to that process of preservation and implementation.").

98. This is not to say that the Equal Protection Clause requires every fundamental right to be extended to the mentally impaired. I simply argue that the state must assert a sufficiently important interest in denying mentally impaired individuals the ability to have such rights exercised on their behalf-the type of interest absent in the instant case of organ donation to immediate family members.

99. 307 N.W.2d 881,893 (Wis. 1981) (" [W]e find it somewhat too facile when discussing the right of privacy, which by definition necessarily refers to the person involved, to find that there is a genuine choice when that choice cannot be personally exercisable.").

100. Id. at 895 . 
"[F]undamental rights may not be submitted to vote; they depend on the outcome of no elections." 101

The reasoning of Valerie $N$. and Quinlan applies to children as well. The Supreme Court has repeatedly held that children are entitled to constitutional rights no less than adults, ${ }^{102}$ although the state may regulate their activities to a greater degree. To say that children do not have the right to donate organs because, due to their age, they lack the legal capacity to consent to the procedure is to miss the point. It is precisely because children cannot exercise this fundamental right for themselves that some form of proxy consent is constitutionally mandated; otherwise they lose the opportunity to exercise the right in the only way possible-through their parent-guardians.

Thus, a standard - whether legislatively or judicially created - that does not permit children or the mentally impaired to donate organs under circumstances in which a competent person might reasonably choose to do so violates the Equal Protection Clause. Given the constitutional undertones of the rights at stake, a system of judicial approval for organ donation by incompetents that in practice never permitted it would also be subject to challenge. ${ }^{103}$ Some sort of legitimate mechanism through which proxy

101. W. Va. Bd. of Educ. v. Barnette, 319 U.S. 624, 638 (1943).

102. Bellotti v. Baird, 443 U.S. 622,635 (1979) (" [C]hildren generally are protected by the same constitutional guarantees against governmental deprivations as are adults ...."); Planned Parenthood v. Danforth, 428 U.S. 52, 74 (1976) ("Minors, as well as adults, are protected by the Constitution and possess constitutional rights."); see, e.g., New Jersey v. T.L.O., 469 U.S. 325, 337-38, 341 (1984) (upholding "reasonable" warrantless school searches of students' property, but noting that " $[\mathrm{a}]$ search of a child's person or of a closed purse or other bag carried on her person, no less than a similar search carried out on an adult, is undoubtedly a severe violation of subjective expectations of privacy"); Parham v. J.R., 442 U.S. 584, 606 (1979) (considering the procedural protections necessary to "protect[] adequately the child's constitutional rights by reducing risks of error without unduly trenching on traditional parental authority" regarding voluntary commitment of children to mental institutions); Ingraham v. Wright, 430 U.S. 651, 674 (1977) (" [A]t least where school authorities, acting under color of state law, deliberately decide to punish a child for misconduct by restraining the child and inflicting appreciable physical pain, we hold that [the child's] Fourteenth Amendment liberty interests are implicated."); Breed v. Jones, 421 U.S. 519 (1975) (holding that the Double Jeopardy Clause protects a minor from being charged with an offense in criminal court for which he has already been adjudicated delinquent in juvenile court); Goss v. Lopez, 419 U.S. 565, 574 (1975) ("[T]he State is constrained to recognize a student's legitimate entitlement to a public education as a property interest which is protected by the Due Process Clause and which may not be taken away for misconduct without adherence to the minimum procedures required by that Clause."); In re Winship, 397 U.S. 358 (1970) (ruling that juveniles have the constitutional right to have charges brought against them in juvenile court proved beyond a reasonable doubt, rather than by a preponderance of the evidence); Tinker v. Des Moines Indep. Cmty. Sch. Dist., 393 U.S. 503, 506 (1969) ("It can hardly be argued that either students or teachers shed their constitutional rights to freedom of speech or expression at the schoolhouse gate."); In re Gaul, 387 U.S. 1, 13 (1967) (upholding the right of children to due process safeguards in delinquency proceedings); Cooper v. Aaron, 358 U.S. 1,17 (1958) (reaffirming "It]he constitutional rights of children not to be discriminated against in school admission on grounds of race or color" in public institutions); Barnette, 319 U.S. 624 (upholding the First Amendment right of schoolchildren not to salute the American flag).

103. A formal mechanism for proxy consent is insufficient if, as a matter of law, it is impossible that such a mechanism would ever allow an organ donation to occur. For instance, the 
consent can be tendered for organ donation by incompetents-and which would in practice actually allow such consent-must exist. The next Part explores what this mechanism should be.

\section{RIGHTS OF PARENTS AND PARENT-GUARDIANS}

In this Part, I argue that the Constitution grants parent-guardians the right to consent to organ donation on behalf of their incompetent wards, without having their decisions reviewed by judges. I begin by rejecting a mode of analysis that some courts have employed in the past to resolve this issue-the doctrine of "substituted judgment." I then show how the ultimate right of parent-guardians to tender proxy consent can be derived from the other traditional framework courts employ in this area-the "best interests" of the prospective donor. Parent-guardians enjoy a constitutionally protected zone of discretion in determining what is in their charges' best interests, within which the decision to tender proxy consent for organ donation squarely falls. I argue that judges may not superimpose their own arbitrary values and preferences over those of the parentguardians.

I then go on, however, to argue that this traditional framework should be rejected, because for parent-guardians to consider only the interests of the incompetent is dehumanizing to him or her. A competent person would

court in In re Richardson, 284 So. $2 d$ 185, 187 (La. Ct. App. 1973), permitted the incompetent's guardian to petition the court to allow a transplant, but declined to authorize the operation because it would have been nontherapeutic to the patient. Although the court was formally open as a mechanism for such petitions, by declining requests where the donation would be nontherapeutic to the incompetent (as all organ donation procedures are), as a matter of law it would be impossible for any such petitions to be approved. Such hollow recourse does not satisfy the demands of the Equal Protection Clause.

An analogous situation can be found in California sterilization legislation enacted in the wake of Valerie $N$. Section 1958(c) of the new code allowed sterilization of incompetents if, among other things, it was found that the incompetent "is capable of engaging in, and is likely to engage in sexual activity at the present or in the near future under circumstances likely to result in pregnancy." CAL. ProB. CODE $§ 1958$ (c) (West 1991). Section 1959, however, stated:

The fact that, due to the nature or severity of his or her disability, a person for whom an authorization to consent to sterilization is sought may be vulnerable to sexual conduct by others that would be deemed unlawful, shall not be considered by the court in determining whether sterilization is to be authorized under this chapter. Id. $\$ 1959$

The problem arose due to section 261 of the California Penal Code, which stated that incompetent people were legally incapable of consenting to sexual intercourse; any form of sexual contact constituted rape. Under the resulting statutory framework, courts could only authorize sterilization if they found the incompetent was likely to engage in intercourse. Because judges were not permitted to consider the possibility of illegal sex acts, and the penal code prohibited all sexual intercourse with incompetents, this criterion could never be fulfilled. The framework thus prevented courts from approving any sterilization petitions. The appellate court refused to uphold such an approach, holding that "section 1959 cannot constitutionally be applied to deny Angela's coconservators the authorization to consent to Angela's sterilization." Conservatorship of Angela D., 83 Cal. Rptr. 2d 411, 420 (Ct. App. 1999). 
normally take into account a wide range of factors beyond self-interest in deciding whether to donate, including the dictates of morality and the interests of the family as a whole. To compel parents to ignore these factors in making proxy consent decisions is fundamentally to disrespect the incompetent and treat him as less than human.

\section{A. The Right of Parent-Guardians To Determine the Best Interests of Their Charges}

This Section explores two separate yet related issues. First, it examines why one of the standards employed by many courts facing this issue-the substituted judgment standard-is patently inappropriate for most situations of this nature. Accepting for the sake of argument the legitimacy of the second common standard applied by many courts in this area ${ }^{104}$ - the best interests standard-this Section goes on to question whether courts should be permitted to overrule determinations of parent-guardians as to whether organ donation is in the best interests of incompetent donors.

\section{Rejecting the Substituted Judgment Standard}

The doctrine of substituted judgment requires a surrogate decisionmaker to "attempt[] to establish, with as much accuracy as possible, what decision the patient would make if he were competent to do so." 105 As one court has noted, "Under the doctrine of substituted judgment, a guardian of a formerly competent, now incompetent, person may look to the person's life history, in all of its diverse complexity, to ascertain the intentions and attitudes which the incompetent person once held." ${ }^{106}$ With regard to nonmature minors and individuals who have been legally incompetent their entire lives, it is impossible to ascertain their "likely treatment/nontreatment preferences" by examining their "philosophical, religious and moral views, life goals, values about the

104. The next Section challenges this assumption.

105. In re Estate of Longeway, 549 N.E.2d 292, 299 (IIl. 1989) (finding that incompetents have a common-law right to refuse artificial hydration or nutrition that may be exercised on their behalf by guardians following a substituted judgment standard).

106. Curran v. Bosze, 566 N.E.2d 1319, 1325 (Ill. 1990) (declining to apply the substituted judgment standard in determining whether three-and-a-half-year-old twins should submit to a bone marrow transplant); see also In re A.C., 573 A.2d 1235, 1251 (D.C. 1990) (" [T]o determine the subjective desires of the patient, the court must consider the totality of the evidence, focusing particularly on written or oral directions concerning treatment to family, friends, and health-care professionals. The court should also take into account the patient's past decisions regarding medical treatment, and attempt to ascertain from what is known about the patient's value system, goals, and desires what the patient would decide if competent."). 
purpose of life and the way it should be lived, and attitudes toward sickness, medical procedures, suffering and death." 107

Consequently, although some courts claim to apply the substituted judgment standard in these cases, ${ }^{108}$ others properly decline to engage in the fiction of doing so. ${ }^{109}$ Neither parents nor courts can be expected to determine how a particular child would feel about donating an organ if she were ten or twenty years older, or how a mentally impaired person would feel about organ donation if she did not suffer from a disability. The substituted judgment test is best left to situations where a previously competent person expressed definite preferences regarding medical treatment, including organ donation, ${ }^{110}$ and due to an accident or some other

107. In re Jobes, 529 A.2d 434, 445 (N.J. 1987) (affirming the right of a husband to have a jejunostomy tube withdrawn from his wife, who was in a permanently vegetative state).

108. E.g., Strunk v. Strunk, 445 S.W.2d 145, 148 (Ky. 1969) (claiming to apply the substituted judgment doctrine where a mother sought to have a kidney from a twenty-seven-yearold incompetent transplanted into his brother, on the ground that "[t]he right to act for the incompetent in all cases has become recognized in this country as the doctrine of substituted judgment and is broad enough not only to cover property but also to cover all matters touching on the well-being of the ward"). In Superintendent of Belchertown State School v. Saikewicz, 370 N.E.2d 417 (Mass. 1977), the court-appointed guardian ad litem of a severely retarded man dying of leukemia petitioned the court for permission to decline chemotherapy on his behalf, on the ground that it would cause him unnecessary suffering while offering little chance of saving his life. In considering the request, the court applied the "substituted judgment" standard, despite the fact that the man had been "profoundly retarded and noncommunicative his entire life, which was spent largely in the highly restrictive atmosphere of an institution." Id. at 430. Basing its conclusion almost entirely on the fact that the substituted judgment doctrine has a "substantial pedigree," the court ruled that "the decision in cases such as this should be that which would be made by the incompetent person, if that person were competent, but taking into account the present and future incompetency of the individual as one of the factors which would necessarily enter into the decision-making process." Id. at 431. The court's reference to such bizarre counterfactuals leads one to conclude that, in cases such as these, the surrogate decisionmaker is simply applying her own opinion as to what she feels is in the best interests of the ward. See John A. Robertson, Organ Donations by Incompetents and the Substituted Judgment Doctrine, 76 COLUM. L. REV. 48, 63 (1976) ("If preferences are unknown, we must act with respect to the preferences a reasonable, competent person in the incompetent's situation would have.").

109. See Parham v. J.R., 442 U.S. 584, 603 (1979) ("Most children, even in adolescence, simply are not able to make sound judgments concerning many decisions, including their need for medical care or treatment. Parents can and must make those judgments."); Curran, 566 N.E.2d at 1326 ("Neither justice nor reality is served by ordering a 31/2-year-old child to submit to a bone marrow harvesting procedure for the benefit of another by a purported application of the doctrine of substituted judgment. Since it is not possible to discover that which does not exist, specifically, whether the 31/2-year-old twins would consent or refuse to consent to the proposed bone marrow harvesting procedure if they were competent, the doctrine of substituted judgment is not relevant and may not be applied in this case."); Jobes, 529 A.2d at 449 ("The 'substituted judgment' approach to decisionmaking for patients in the persistent vegetative state is our ideal. We realize that in some cases it may be unworkable, e.g., when the patient has always been incompetent."); see also Schwartz, supra note 16, at 427 ("It is somewhat far-fetched for courts to seek to determine what the incompetent would have wanted if he could have made a utilitarian inquiry. It is almost incredulous to believe that courts should try to determine the incompetent's putative ethical outlook as well.").

110. My arguments throughout the remainder of this Note, that the substituted judgment standard should be abandoned and parents should have the final word in proxy consent decisions, do not apply in the rare case where the incompetent donor had once been competent and expressed his values and beliefs to a degree sufficient to allow meaningful application of the 
intervening circumstance, is later unable to effectuate her wishes on her own. ${ }^{11}$

\section{Deciding on a Decisionmaker}

Whether explicitly or while claiming to apply the substituted judgment doctrine, many courts take it upon themselves to apply a best interests test to determine whether organ donation by an incompetent should be permitted. ${ }^{112}$ In doing so, regardless of whether they reject or ratify the decision of the parent-guardians, judges displace parent-guardians as the ultimate arbiters of the best interests of incompetent donors. Even assuming that the best interests standard is the proper test to apply, ${ }^{113}$ allowing courts to usurp the role of parent-guardians in these circumstances is unconstitutional.

For parents, "freedom of personal choice in matters of family life is a fundamental liberty interest protected by the Fourteenth Amendment ... [extending to] the care, custody, and management of their child." 114 Consequently, in general, children's parents and the parent-guardians of the mentally impaired have the right to consent on their behalf to medical treatment. ${ }^{15}$ Due to the nature of the family and the general relationship between guardians and those for whom they are responsible, it is assumed that decisions made by parent-guardians are in the best interests of their

substituted judgment test. In such cases, respect for individual autonomy requires that the wishes of the incompetent donor be respected. See Cruzan v. Dir., Mo. Dep't of Health, 497 U.S. 261, 280 (1990) (ruling that a statutory scheme for allowing family members to terminate life support of permanently vegetative patients was constitutional because it ensured that the "action of the surrogate conforms as best it may to the wishes expressed by the patient while competent").

111. See, e.g., id.; In re Quinlan, 355 A.2d 647, 666 (N.J. 1976) (holding that the substituted judgment standard was appropriate to determine whether parents of a twenty-one-year-old woman may have her feeding tubes removed, where the woman had previously been competent but for unknown reasons had lapsed into a pcrmanent vegetative state). For an excellent in-depth analysis of the Cruzan decision, see John A. Robertson, Cruzan and the Constitutional Status of Nontreatment Decisions for Incompetent Patients, 25 GA. L. REV. 1139 (1991). For an interesting discussion of the history of the substituted judgment test and the best interests test, see Louise Harmon, Falling off the Vine: Legal Fictions and the Doctrine of Substituted Judgment, 100 YALE L.J. 1 (1990).

112. In Strunk, after declaring that it would apply the doctrine of substituted judgment, see supra note 108 , the court declared it would authorize the operation because the lower court had "found that the operative procedures in this instance [were] to the best interest of [the ward] and this finding [had] been based upon substantial evidence." 445 S.W.2d at 149; $c f$. Little v. Little, 576 S.W.2d 493, 498 (Tex. App. 1979) (basing its conclusions "on the benefits that the incompetent donor would derive, rather than on the theory that the incompetent would have consented to the transplant if he were competent").

113. This assumption is challenged in Section III.B.

114. Santosky v. Kramer, 455 U.S. 745,753 (1982) (discussing the evidentiary burden in proceedings to terminate parents' relationships with their children permanently).

115. See supra note 13 and accompanying text. 
charges, and thus such decisions must be accorded great deference. ${ }^{116}$ As the United States Supreme Court declared,

The law's concept of the family rests on a presumption that parents possess what a child lacks in maturity, experience, and capacity for judgment required for making life's difficult decisions. More important, historically [the law] has recognized that natural bonds of affection lead parents to act in the best interests of their children. ${ }^{117}$

Allowing courts to engage in an essentially de novo review of proxy consent decisions is inconsistent with these constitutional principles.

Typically, parent-guardians are excluded from deciding what is in the best interests of their charges only when "the balance of risks and benefits [is] so one-sided that it is unlikely that a parent who would deny this type of treatment is looking out for the child's best interests." "118 Parents have the "well established legal right to make important decisions for their children.... [T] he State has the burden of proving by clear and convincing evidence that intervening in the parent-child relationship is necessary to ensure the safety or health of the child, or to protect the public at large." 119 Such a burden cannot be met with regard to proxy consent for organ donation.

Consider the line of cases involving parental health-care decisions for children. Courts have repeatedly stressed that parents "may not deprive a child of lifesaving treatment, however well intentioned. ... Even when the parents' decision to decline necessary treatment is based on constitutional grounds, such as religious beliefs, it must yield to the State's interests, as parens patriae, in protecting the health and welfare of the child." 120

116. See Moore v. City of E. Cleveland, 431 U.S. 494, 503-04 (1977) ("Our decisions establish that the Constitution protects the sanctity of the family precisely because the institution of the family is deeply rooted in this Nation's history and tradition. It is through the family that we inculcate and pass down many of our most cherished values, moral and cultural."); Prince v. Massachusetts, 321 U.S. 158, 166 (1944) ("It is cardinal with us that the custody, care and nurture of the child reside first in the parents, whose primary function and freedom include preparations for obligations the state can neither supply nor hinder."); Wolinski v. Browneller, 693 A.2d 30, 42 (Md. 1997) (noting the presumption that parents act in the best interests of children); In re Penny N., 414 A.2d 541, 542-43 (N.H. 1980) (per curiam) (holding that an incapacitated minor's parents are joint guardians and are presumed to make decisions in the daughter's best interests).

117. Parham v. J.R., 442 U.S. 584, 602 (1979). See generally Arthur J. Dyck, SelfDetermination and Moral Responsibility, 9 W. NEW ENG. L. REV. 53, 55-60 (1987) (discussing family involvement in medical decisions in the context of the doctrine of self-determination).

118. Rosato, supra note 15 , at 55.

119. Newmark v. Williams, 588 A.2d 1108,1110 (Del. 1991) (holding that the state cannot take custody of a minor suffering from a form of cancer known as Burkitt's Lymphoma due to his parents' refusal to consent to "an extremely risky, toxic, and dangerously life threatening medical treatment offering less than a $40 \%$ chance for "success"").

120. Crouse-Irving Mem. Hosp., Inc. v. Paddock, 485 N.Y.S.2d 443, 444-45 (Sup. Ct. 1985) (citations omitted); see also Custody of a Minor, 379 N.E.2d 1053, 1056 (Mass. 1978) (holding 
Nonetheless, the state's ability to overrule parental decisions in cases such as these may be utilized only when the parents' choice is patently unreasonable by conventional standards and squarely against the child's interests. Parental rights "do not clothe parents with life and death authority over their children," ${ }^{121}$ but they do demand deference in less extreme situations. As Part I demonstrated, the risks surrounding organ donation are small; this is not the type of "one-sided" determination that demands judicial review. ${ }^{122}$

Where grave interests are not at stake, or reasonable people can disagree over the proper resolution, the judgment of the parent-guardian should be respected. As a Missouri court noted, where "there is a difference of medical opinion as to the efficacy of a proposed treatment, or where medical opinion differs as to which of two or more suggested remedies should be followed, requiring the exercise of a sound discretion, the opinion of the parent should not be lightly overridden." 123

It can be argued that courts could play a legitimate role if the substituted judgment standard were appropriate in these situations. ${ }^{124}$ Under

that "the State may intervene when parents decline to administer the only type of medical treatment which evidence before the court indicates could save their child's life... [F]amily autonomy is not absolute, and may be limited where... parental decisions will jeopardize the health or safety of their child" (internal quotation marks and citations omitted)).

121. In re McCauley, 565 N.E.2d 411,413 (Mass. 1991) (permitting the state to compel a blood transfusion for a minor child over the religious objections of the parents, who were Jehovah's Witnesses); see also Novak v. Cobb County-Kennestone Hosp. Auth., 849 F. Supp. 1559 (N.D. Ga. 1994) (holding that a public hospital was not liable for violating the civil rights of a Jehovah's Witness minor by providing a blood transfusion over the religious objections of both the minor and his parents). The Georgia court explained: "[T]he [United States] Supreme Court firmly established that a parent's religious freedom is subordinate to the state's interest in preserving the health and welfare of the children within its borders." Id. at 1571 n.16 (citing Prince v. Massachusetts, 321 U.S. 158 (1944)). The court continued: "Not even a parent has unbridled discretion to exercise their religious beliefs when the state's interest in preserving the health of children within its borders weighs in the balance." Id at 1575 .

122. At issue here is the donation of nonvital organs, the giving of which will not substantially impair any major life activities of the donor. The risk to the donor is small, and the donation will have no long-term impact on the donor's major life activities. See supra notes 33-51 and accompanying text.

Of course, it is possible that special medical circumstances can complicate donation by a particular minor, substantially impacting the safety or likelihood of success of the procedure and so endangering the medical welfare of the potential donor to such a degree as to warrant judicial intervention. As this Section has repeatedly stressed, parents' authority over their children does not extend to decisions seriously jeopardizing their lives. See supra notes 118-121 and accompanying text. Nonetheless, given the current state of transplant technology, such judicial intervention should be rare, and not a consequence of the standard risks discussed in Part I.

123. Morrison v. State, 252 S.W.2d 97, 102 (Mo. Ct. App. 1952) (holding that a court may order blood transfusions to a child over the religious objections of the parents when necessary to save the child's life).

124. As discussed in the previous Subsection, however, the substituted judgment standard is generally inappropriate in these cases, because it leaves parents in the untenable position of having to prove what children or mentally impaired people would choose for themselves, absent their youth or mental disability. It should only be used where a previously competent individual has become incompetent. See supra notes 105-111 and accompanying text. 
the substituted judgment standard, parent-guardians would be responsible for proving an objective fact-that the potential donor would have consented to the transplant. When the best interests standard is applied to organ donation, however, parents are left attempting to persuade the court to adopt a subjective, value-oriented judgment; any objective issues that do exist are vastly overshadowed by moral issues. The Constitution has been interpreted as leaving these types of decisions to parents.

Those courts that have taken it upon themselves to determine whether organ donation would be in the best interests of incompetent donors have used tremendously varying approaches. One court, without explicitly ruling that a transplant would be in the best interests of the donor, found that removing a kidney from a seven-year-old girl for implantation in her dying twin sister was permissible because

if the expected successful results are achieved they would be of immense benefit to the donor in that the donor would be better off in a family that was happy than in a family that was distressed and in that it would be a very great loss to the donor if the donee were to die from her illness. ${ }^{125}$

The Texas court in Little $v$. Little similarly found persuasive the fact that "[s]tudies of persons who have donated kidneys reveal resulting positive benefits such as heightened self-esteem, enhanced status in the family, renewed meaning in life, and other positive feelings including transcendental or peak experiences flowing from their gift of life to another." ${ }^{126}$ Such reasoning is unpersuasive given that the very reason proxy consent was necessary is that incompetents are not capable of fully understanding the consequences of donation, as the participants in such studies undoubtedly were.

Another court took a different approach, construing "best interests" more narrowly and finding that the survival of the organ recipient was a relevant consideration only because the potential recipient had been "the sole family member to have become involved in placement and treatment decisions for the incompetent in the past and will likely continue to do so." 127

In contrast, a Louisiana court concluded "that surgical intrusion and loss of a kidney clearly would be against [the incompetent donor's] best interest," without providing any reasoning or analysis, notwithstanding the fact that the recipient was to have been the donor's sister ${ }^{128}$ In a similar

125. Hart v. Brown, 289 A.2d 386, 389 (Conn. Super. Ct. 1992).

126. Little v. Little, 576 S.W.2d 493, 499 (Tex. App. 1979).

127. In re Doe, 481 N.Y.S.2d 932, 933 (App. Div. 1984).

128. In re Richardson, 284 So.2d 185, 187 (La. Ct. App. 1973). 
case, the Wisconsin Supreme Court reached the same conclusion, blocking a transplant from an incompetent donor to his sister because "[ $t$ ]here is absolutely no evidence here that any interests of the ward will be served by the transplant." ${ }^{22}$ A Kentucky judge, in a dissent, agreed that proxy consent for organ donation should be prohibited because the procedure is not "of significant benefit to the incompetent." 130

Such subjective, indeterminate, and widely varying conclusions in the face of similar fact patterns, based on no criteria other than those that individual judges arbitrarily choose to impose, should not be permitted to override the constitutionally protected decisions of those who care most for both the potential donor and donee, and who must live in the aftermath of whatever decision is ultimately made. ${ }^{131}$

\section{B. Rejecting the Best Interests Test}

The previous Section demonstrated that parental decisions regarding proxy consent are constitutionally protected under the best interests framework. In this Section, I reject that framework and argue that parents have the right to consider a much wider range of factors than merely the best interests of the potential donor. While in practice this will not make a difference (because in either case the decision of the parent-guardian is unreviewable), this latter approach is more respectful of children and the mentally impaired and assures parents that they are justified in considering many of the factors their hearts might find relevant, but that the best interests test (at least as applied by some courts) would not.

\section{Morality Requires the Best Interests Test Be Rejected}

"To protect the incompetent person within its power, the State must recognize the dignity and worth of such a person and afford to that person

129. In re Guardianship of Pescinski, 226 N.W.2d 180, 181 (Wis. 1975).

130. Strunk v. Strunk, 445 S.W.2d 145, 151 (Ky. 1969) (Steinfeld, J., dissenting).

131. In Bonner v. Moran, 126 F.2d 121 (D.C. Cir. 1941), the court was faced with a fifteenyear-old boy who had been brought to the hospital by his aunt, without his mother's knowledge, to donate skin grafts to help his cousin recover from severe burns. The mother sued for battery, alleging that the doctors had operated upon the boy without her consent. The circuit court ruled that the trial court had erred in instructing the jury that there existed the equivalent of a "mature minor" exception to the general requirement for parental consent for surgery on minors. The circuit court stated that where a minor is the subject of "a surgical operation not for the benefit of the person operated on but for another [and that is] so involved in its technique as to require a mature mind to understand precisely what the donor was offering to give[,] ... the consent of the parent was necessary." Id. at 123 . The Bonner court was more focused on the general principles of battery and informed consent than on the right of parent-guardians to consent on behalf of their charges to donate organs. Bonner was not cited in any of the subsequent state cases concerning proxy consent discussed in this Section. Its lack of analysis or reasoning concerning proxy consent renders it of little precedential value in this area. 
the same panoply of rights and choices it recognizes in competent persons." ${ }^{132}$ The best interests test is justified as a way to avoid exploitation by ensuring that parent-guardians act only for the benefit of their wards. ${ }^{133}$ However, the test, in ostensibly protecting incompetent potential donors, in fact strips them of their humanity and reduces them to mere vortices for resources and benefits.

This point appears to have been recognized by only one judge who, dissenting from the majority's decision to block a kidney transplant from an incompetent donor to his sister, wrote,

The majority opinion would forever condemn the incompetent to be always a receiver, a taker, but never a giver. For in holding that only those things which financially or physically benefit the incompetent may be done by the court, he is forever excluded from doing the decent thing, the charitable thing. ${ }^{134}$

People in the real world are motivated by factors other than direct personal gain; ${ }^{135}$ especially when family members are in need, people are often motivated by altruism and empathy. ${ }^{136}$ The best interests test, however, discounts most of the factors that a competent person deciding to donate would consider relevant. To prohibit consideration of factors other than self-interest to which most competent individuals would lend serious

132. Superintendent of Belchertown State Sch. v. Saikewicz, 370 N.E.2d 417, 428 (Mass. 1977).

133. See, e.g., Pescinski, 226 N.W.2d at 182 (declining to allow proxy consent for a kidney donation from a legally incompetent donor because "[a]n incompetent particularly should have his own interests protected. Certainly no advantage should be taken of him"); IMMANUEL KANT, Foundations of THE METAPHYSICS OF MORALS 52 (Robert Paul Wolff ed. \& Lewis White Beck trans., Bobbs-Merrill Co. 1969) (1785) ("[E]very rational being cxists as an end in himself and not merely as a means to be arbitrarily used by this or that will.").

134. Pescinski, 226 N.W.2d at 184 (Day, J., dissenting).

135. Some philosophers, advocating "psychological egoism," have argued that "all human actions when properly understood can be seen to be motivated by selfish desires." Jocl Feinberg, Psychological Egoism, in REASON AND RESPONSIBILITY 497, 497 (Joel Feinberg ed., 9th ed. 1996). Such theorists recognize, however, that people often act for the benefit of others. They merely argue that such apparently altruistic acts are in fact selfish because of the feelings of satisfaction people derive from performing them. See id.

136. MARK J. ChERRY, PERSONS AND TheIR BoDIES 6 (1999) (" [A]ltruism is believed to support individual freedom by fostering personal choice. ... [A] ltruism on the part of the donor may be a real motivating factor." (internal quotation marks omitted)). For a consideration of this matter from an evolutionary biology perspective, see JAMES R. OZINGA, ALTRUISM 13 (1999). Ozinga states:

Selfishness may be important, but it is not enough. Concern for one's own germ line needs to take others into account both because of the possible importance of those others to one's own germ line and also because cooperation with others is part of what being human is all about. ... Altruism is an instinct for survival that may be in our Id. genes-an internal force for goodness in everyone that begins with birth. 
weight is to disrespect incompetents. ${ }^{137}$ To assume that a legally incompetent person should be treated as "always a receiver, a taker, but never a giver," 138 is to treat that person as less than fully human.

Moreover, courts have explicitly recognized that organ donation to family members is a moral, albeit not legal, obligation. In the words of one judge, "Morally, this decision rests with defendant [a potential donor] and, in the view of the court, the refusal of defendant is morally indefensible." 139 For the state to preclude parent-guardians from consenting on behalf of their wards to do the right thing is to strip children and the mentally impaired of their dignity by exempting them from the moral obligations incumbent upon members of families. ${ }^{140}$

To say, as some courts have, that proxy consent is permissible because of the instrumental value of the saved lives to the donor sibling seems at best disingenuous and at worst to miss what is truly at stake in these decisions. People sacrifice for family members. To act as if incompetents should never be called upon to do so is to disvalue their role as legitimate members of the family and to disrespect them in a subtle yet particularly invidious way.

Incompetents cannot be condemned for failing to heed their moral duties because they generally are not aware of them or are not in a position to fulfill them; these moral duties nonetheless exist. ${ }^{141}$ Although there are

137. Indeed, when a family member is in need of a transplant, "the majority of donors volunteer immediately upon hearing of the need without any time delay or any period of deliberation." ROBERTA G. SIMMONS ET AL., GIFT OF LIFE: THE SOCIAL AND PSyCHOLOGICAL IMPACT OF ORGAN TRANSPLANTATION 241 (1977); see also Aaron Spital, Ethical Issues in Living Organ Donation: Donor Autonomy and Beyond, 38 AM. J. KIDNEY DISEASES 189, 192 (2001) "When the health of a loved one is at stake . . many people will want to donate almost regardless of the risks involved.").

138. Pescinski, 226 N.W.2d at 184 (Day, J., dissenting).

139. McFall v. Shimp, 10 Pa. D. \& C.3d 90, 91 (C.P. 1978) (holding that the plaintiff may not compel the defendant, the only compatible bone-marrow donor, to undergo a bone-marrow transplant).

140. See Eike-Henner W. Kluge, Designated Organ Donation: Private Choice in Social Context, in LIFE CHOICES 503, 508 (Joseph H. Howell \& William Frederick Sale eds., $2 \mathrm{~d}$ ed. 2000) (arguing that parents have a moral duty to donate organs to their children); Thomas $H$. Murray, Altruism and Health Care: What Community Shall We Be?, in 3 ALTRUISM, SOCIETY, HEALTH CARE 67, 73 (Anders Nordgren \& Claes-Göran Westrin eds., 1996) (“[T]he power of family loyalty, the sense of dedication to each other's welfare ... makes the decision to donate a kidney so obviously and overwhelmingly 'right' that for a great many people it requires no further reflection.").

141. See Shannon M. JORDAN, Decision MAKING FOR INCOMPETENT PERSONS 59-60 (1985). Jordan writes:

[T] ine incompetent person is not merely an animal organism whose experience of pleasure and pain places certain obligations on the rest of us; rather, what follows is that the incompetent is a person, in traditional terms, because he is a rational being. He is a rational being because his life depends on rational activity. ... The incompetent person cannot exist at all on his own initiative, whether instinctive or rational. The incompetent person exists only through a dynamic relation with other persons who Id. provide rational intentional actions for him. 
limits to the level of altruism that parent-guardians can require of those in their care, ${ }^{142}$ it degrades children and the mentally impaired to prevent their guardians from doing the right thing, and instead to force them always to follow the path of their wards' self-interest.

\section{Precedent Allows the Best Interests Test To Be Rejected}

"The best interests of the child," a venerable phrase familiar from divorce proceedings, is a proper and feasible criterion for making the decision as to which of two parents will be accorded custody. But it is not traditionally the sole criterion-much less the sole constitutional criterion-for other, less narrowly channeled judgments involving children, where their interests conflict in varying degrees with the interests of others. ${ }^{143}$

So wrote the Supreme Court in holding that the INS can detain illegal alien children who had no families in the United States in government facilities, despite the fact that it would be undeniably better for the children to be temporarily placed with foster families. Referring to general principles of family law, the Court noted, "So long as certain minimum requirements of child care are met, the interests of the child may be subordinated to the interests of other children, or indeed even to the interests of the parents or guardians themselves." 144

Families, especially immediate families, are fundamental units in our society, and to treat each member as a self-interest-maximizer is to misconstrue the nature of familial relations. Many important decisions are normally made based on the best interests of the family-children take on after-school jobs, high school graduates forego attending expensive institutions of higher learning, close friends and significant others are left behind for a cross-country move. In poorer families, health care itself is rationed, and the cost of visits to the doctor's office is balanced against the needs of others in the family. ${ }^{145}$ Family members regularly are called upon

142. Prince v. Massachusetts, 321 U.S. 158, 170 (1944) ("Parents may be free to become martyrs themselves. But it does not follow that they are free ... to make martyrs of their children before they have reached the age of full and legal discretion when they can make that choice for themselves.").

143. Reno v. Flores, 507 U.S. 292, 303-04 (1993) (holding that the INS may detain illegal aljen minors even when families are willing to take nonadoptive custody of the minor).

144. Id. at 304 .

145. See F. Allan Hubbell et al, Evaluating Health-Care Needs of the Poor: A CommunityOriented Approach, 87 AM. J. MED. 127, 129 (1989) ("Reasons that people lacked a regular source of [medical] care included lack of health insurance, inadequate financial resources, [and] outstanding medical bills ...."); see also RENEE C. FOX \& JuDITH P. SWAZEY, SPARE PARTS: ORGAN REPLACEMENT IN AMERICAN SOCIETY 86 (1992) ("[O]ur society does indeed ration health care based on an ability to pay..."); Chris Hafner-Eaton, Physician Utilization Disparities Between the Uninsured and Insured: Comparisons of the Chronically Ill, Acutely IIl, and Well Nonelderly Populations, 269 JAMA 787, 787 (1993) (“Americans without insurance or 
to sacrifice for each other, and parents are most often the ones responsible for managing the allocation of burdens and responsibilities. "The role of parents in the life of a family has attained the status of a fundamental human right and liberty." 146

In ruling that a court may not compel an unwilling, competent individual to become an organ donor, a Pennsylvania court accurately noted, "Our society, contrary to many others, has as its first principle, the respect for the individual, and that society and government exist to protect the individual from being invaded and hurt by another." 147 However accurate this depiction of the relationship among individuals in society at large may be, it would be a gross distortion to characterize familial relationships in a similar manner. Family members - parents, children, adolescents, and adult incompetents living under their care-owe responsibilities toward each other that do not exist among members of society at large.

The Pennsylvania court went on to declare, "For a society which respects the rights of one individual, to sink its teeth into the jugular vein or neck of one of its members and suck from it sustenance for another member, is revolting to our hard-wrought concepts of jurisprudence." 148 Notwithstanding the harsh and unappealing rhetoric with which this sentiment is expressed, such interdependence is an essential feature of families.

Moreover, the rights of marriage and procreation long secured by the Supreme Court ensure the right of parents to form families. ${ }^{149}$ This right to create a family necessarily implies the right to make decisions concerning family members required to maintain the family. As the Supreme Court wrote in Moore v. City of East Cleveland, "[U]nless we close our eyes to the basic reasons why certain rights associated with the family have been accorded shelter under the Fourteenth Amendment's Due Process Clause,

public coverage are less likely to have their children immunized, seek early prenatal care ... or see a physician ....").

146. State v. H., 393 A.2d 1387, 1388 (N.H. 1978); see also Lassiter v. Dep't of Soc. Servs., 452 U.S. 18, 38 (1981) (recognizing the "centrality of family life as the focus for personal meaning and responsibility"); International Covenant on Civil and Political Rights, adopted Dec. 19, 1966, art. 23, \& 1, S. EXEC. DOC. E, 95-2, at 30 (1978), 999 U.N.T.S. 171, 179 ("The family is the natural and fundamental group unit of society and is entitled to protection by society and the State.").

147. McFall v. Shimp, 10 Pa. D. \& C.3d 90, 91 (C.P. 1978).

148. Id.

149. Eisenstadt v. Baird, 405 U.S. 438, 453 (1972) ("If the right of privacy means anything, it is the right of the individual, married or single, to be free from unwarranted governmental intrusion into matters so fundamentally affecting a person as the decision whether to bear or beget a child."); Loving v. Virginia, 388 U.S. 1, 12 (1967) ("Marriage is one of the 'basic civil rights of man,' fundamental to our very existence and survival .... The Fourteenth Amendment requires that the freedom of choice to marry not be restricted by invidious racial discriminations." (quoting Skinner v. Oklahoma, 316 U.S. 535, 541 (1942))). 
we cannot avoid applying the force and rationale of these precedents to the family choice involved in this case." ${ }^{150}$ It is grossly inconsistent with other acknowledged legal rights, the reality of family life, and the moral obligations family members generally owe one another to hold that parents may not base a decision to issue proxy consent for organ donation on the interests of the family.

Such a conclusion seems to be implicit in the court's ruling in Hart $v$. Brown. ${ }^{151}$ The court never explicitly ruled that the operation would be in the best interests of the donor, but instead stated, "To prohibit the natural parents and the guardians ad litem of the minor children the right to give their consent under these circumstances, where there is supervision by this court and other persons in examining their judgment, would be most unjust, inequitable and injudicious." 152 The ruling was not based on the donor's best interests so much as on what the judges found to be the absurd unfairness of preventing a parent from allowing her child to save the life of her sibling. The court considered the totality of the situation, rather than solely taking into account the best interests of the child, in determining what outcome would be "unjust, inequitable and injudicious." 153 The only roughly analogous situation is the virtually unchallenged authority parents have to consent to the surgical separation of Siamese twins, where the twins may be able both to live if conjoined, and one is virtually guaranteed to die upon separation. ${ }^{154}$

Under current law, parent-guardians enjoy the constitutional right, and have the moral duty, to take factors other than the best interests of the potential donor into account. Among other things, these factors are likely to include the demands of morality and the best interests of the family as a whole. Instead of focusing on the instrumental value to the potential organ recipient-that is, how much saving the life of a close relative is in the best interests of a potential incompetent donor-courts should recognize that parent-guardians have the right to view such important decisions as something more than simply calculations of utility.

150. 431 U.S. 494, 501 (1977).

151. 289 A.2d 386 (Conn. Super. Ct. 1972).

152. Id. at 378

153. Id.

154. See Maria Malave \& Jessie Graham, Loving Mom at Peace with Siamese Twins, N.Y. POST, Apr. 13, 2001, at 6 ("Marrero's doctor suggested she contact another family, which had traveled to New York-Presbyterian from the mountains of Puerto Rico for an operation-last October to separate their Siamese twins. One of those infants, Janlee, died of heart failure two days after the surgery."); see also The Moral Dilemma of Siamese Twins, NEWSWEEK, June 22, 1981 , at 40. 


\section{BEARING CHILDREN TO BE ORGAN DONORS}

The right of parent-guardians to tender proxy consent to organ donation on behalf of their wards will undoubtedly lead to situations where parents conceive and give birth specifically so that the new baby can act as an organ donor. Indeed, this is what happened in the highly publicized Ayala case, wherein parents of a young girl dying of chronic myelogenous leukemia conceived a new child in the hope that it would be a compatible bone-marrow donor. ${ }^{155}$ The Ayala case is by no means isolated; according to one survey, at least forty bone marrow transplants involved a donor whose birth was primarily motivated by the need for compatible bone marrow. ${ }^{156}$ As somatic cell nuclear transfer, or cloning, technology develops, parents can be assured that the child to whom they give birth will be a compatible organ or bone marrow donor, ${ }^{157}$ and such occurrences are likely to be even more frequent.

Many commentators have criticized this not only as an inappropriate reason for having children, but as an immoral objectification of the donor child that leads parents to view it as instrumentally valuable for its organs, rather than as inherently valuable. ${ }^{158}$ Defenders respond that the practicewhether accomplished through natural conception, genetic selection, or cloning -is acceptable, as long as parents are willing to love and accept the child whether or not it is a compatible donor. ${ }^{159}$ "If the parents are willing $3 \mathrm{~A}$.

155. Sally Ann Stewart, Toddler May Be Sister's Lifesaver, USA TODAY, June 4, 1991, at

156. Matthew B. Hsu, Banning Human Cloning: An Acceptable Limit on Scientific Inquiry or an Unconstitutional Restriction of Symbolic Speech?, 87 GEO. L.J. 2399, 2425 n.200 (1999) (“'A] survey of bone marrow transplant centers indicated that 40 such cases of parents conceiving a child to serve as a bone marrow donor existed.").

157. Mary B. Mahowald, Genes, Clones, and Gender Equality, 3 DePAul J. Health Care L. 495, 514 (2000) ("If the Ayala family could have cloned Anissa to produce another child, they would have thereby insured a match for bone marrow donation to her.").

158. Stephanie J. Hong, And "Cloning" Makes Three: A Constitutional Comparison Between Cloning and Other Assisted Reproductive Technologies, 26 HASTINGS CONST. L.Q. 741, 780 (1999) ("There are, however, some commodification-objectification concerns in creating a child simply to produce an organ or tissue donor."); Mahowald, supra note 157, at 513 ("In Kantian language, the obvious moral problem raised by such a situation is that a person is treated as a means rather than an end."); see also Anastasia Toufexis, Creating a Child To Save Another, TIME, Mar. 5, 1990, at 56 ("Children aren't medicine for other people." (quoting Prof. George Annas)).

159. See, e.g., Hsu, supra note 156, at 2425 ("[C]hildren cloned to provide donor tissue will not necessarily be valued any less than children currently being conceived to provide tissue for a sick older sibling. In fact, children who were bom to provide tissue for an older sibling are cherished as children in their own right and also as the life-savers of their older brother or sister."); Mahowald, supra note 157, at 513 ("Regardless of whether the infant was a tissue match for their daughter, however, they said they would love and care for the child as fully as they loved and cared for Anissa. In other words, their motives were mixed, as is true of most people most of the time."). 
to welcome and raise a new child, why would the fact that the new baby is guaranteed to save a sibling's life weigh against the conception?" 160

Putting aside the thorny issue of human cloning, a prohibition on conceiving children for the purpose of consenting to donate their organs would be patently unconstitutional. As the Supreme Court declared in Eisenstadt v. Baird, "If the right to privacy means anything, it is the right of the individual, married or single, to be free from unwarranted governmental intrusion into matters so fundamentally affecting a person as the decision whether to bear or beget a child." 161

Even from an ethical standpoint, it is unclear that the practice should be subject to condemnation. Opponents might claim that children could somehow be psychologically harmed by the knowledge that they were conceived primarily for their organs. Far from being a decisive argument against conception, however, this claim gives rise to what in philosophical circles is referred to as the "future person" problem. It is difficult to claim that being born for a particular reason (or through a particular type of advanced reproductive technology) is against a child's best interests, or inflicts a net harm on that child. But for that parental motive or advanced technology, the child would not exist. Put another way, one cannot easily say that a child whose conception was primarily motivated by the need for a kidney or bone marrow is wronged, because the alternative for that child is never to have been born at all. ${ }^{162}$

Furthermore, conceiving a child to save a life is hardly a motive that warrants moral condemnation, even from the perspective of the child herself. After all, the child "might well prefer that to the idea that one was an 'accident,' ... [conceived] because contraception or abortion were not available, conceived to cement a failing marriage, to continue a family line, to qualify for welfare aid, to sex-balance a family, or as an experiment in child-rearing." 163 People conceive and give birth to children for a wide

160. Jennifer S. Bard, The Diagnosis Is Anencephaly and the Parents Ask About Organ Donation: Now What? A Guide for Hospital Counsel and Ethics Committees, 21 W. NEW ENG. L. REV. 49, 72 n.140 (1999).

161. 405 U.S. 438, 453 (1972); see also JOHN A. ROBERTSON, CHILDREN OF CHOICE 217 (1994) (" [P]rocreative liberty should include the right to have children for any motive, including to serve as a marrow donor, if such goals or uses of the child independently respect that child's interests.").

162. The "future person" problem has been analyzed extensively as applied to human cloning. Robertson writes, "[T] he potentially harmful effects of cloning cannot truly harm the clone, because there is no unharmed state, other than non-existence, that could be achieved as a point of comparison. If cloning did not occur, the cloned individual would not exist." ROBERTSON, supra note 161, at 169; see also Philip G. Peters, Jr., Harming Future Persons: Obligations to the Children of Reproductive Technology, 8 S. CAL. INTERDISC. L.J. 375 (1999) (discussing the "future persons" problem).

163. Laura M. Purdy, Surrogate Mothering: Exploitation or Empowerment?, in BIOETHICS 103, 108-09 (Peter Singer \& Helga Kuhse eds., 1999). 
range of reasons, and often for mixed reasons or even no reason at all..$^{164}$ In light of some of the commonly accepted purposes for giving birth, doing so to save a life can hardly be a ground for moral reproach. For these reasons, the possibility of parents giving birth to children to act as organ donors does not constitute a compelling argument against recognizing the right of parent-guardians to tender proxy consent.

\section{CONCLUSION}

Kathleen Hart's life was saved because her parents were able to offer proxy consent for kidney donation by her twin sister. ${ }^{165}$ Others were not so lucky. ${ }^{166}$ Such deaths could be avoided through the recognition of the constitutional right of incompetent persons to donate their organs to save the lives of immediate family members. Because the right to make such donations is an important aspect of the positive right to bodily integrity, the right to privacy, and notions of fundamental liberty, the Equal Protection Clause requires that states permit this right-like the right to sterilization and the right to have lifesaving measures terminated - to be exercised on behalf of incompetents.

The decision of parent-guardians to tender proxy consent should not be second-guessed by the courts. Whether or not one feels that parentguardians are bound only to consider the best interests of the potential donor, final resolution of the issue is constitutionally committed to their sole discretion. Because it is a highly subjective matter, heavily infused with subjective value judgments as opposed to objective facts, the decision of the parents should be respected.

To ignore the fact that many competent people would be willing to donate an organ to save the life of a family member-not merely for the benefits that would accrue to the donor from having that family member survive, but simply because doing so is in the nature of belonging to a

164. Kenneth Alpern, listing reasons that motivate people to have children, notes:

Having children is a cultural norm (it is the natural thing to do); it is expected by parents, peers, religions; it may even be felt to be a duty or fulfillment of God's command. ... [ [t] gives significance to marriage or to the personal relationship of two people; children symbolize, express, and actualize the union of the parents. . . . [It] is a way of continuing oneself, one's line (family, bloodline, geneline), and one's species. ... Having children is an activity of creation, participation in something beyond oneself; it gives a sense of power, competence, coming of age, and gender realization; it proves to oneself and to others one's independence and maturity. Children are sources of labor and of physical and emotional support, especially in old age.

Kenneth D. Alpern, Genetic Puzzles and Stork Stories: On the Meaning and Significance of Having Children, in THE ETHICS OF RePRODUCTIVE TECHNOLOGY 147, 151-52 (Kenneth D. Alpern ed., 1992).

165. Hart v. Brown, 289 A.2d 386 (Conn. Super. Ct. 1972).

166. See supra note 18 . 
family-is to neglect a crucial dimension of the issue. Thus, parentguardians should not be limited to considering only the best interests of the child in making this decision. To insist that self-interest, narrowly defined, should take precedence over the demands of morality for children and the mentally impaired is to deny members of both groups the dignity of being treated, even indirectly, as players on the stage of morality. 
*将

Imaged with the Permission of Yale Law Journal 